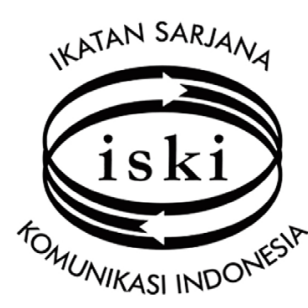

Jurnal Komunikasi. 01 (2016) 12-24

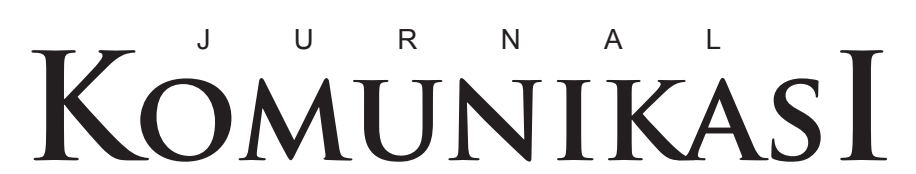

e-ISSN: ---- ------

p-ISSN: ---- --- ---

IKATAN SARJANA KOMUNIKASI INDONESIA

\title{
MODEL PUBLIC RELATIONS UNTUK PEMBANGUNAN REPUTASI PENDIDIKAN MENENGAH SEBAGAI SEKOLAH RUJUKAN BERPRESTASI BERPOTENSI
}

\author{
Agus Naryoso \\ Ilmu Komunikasi Universitas Diponegoro
}

\begin{abstract}
Abstrak:
Perkembangan kualitas pendidikan menengah SMA, SMK, MA belum menunjukkan kemajuan signifikan. Kondisi tersebut banyak disebabkan selain jumlah guru yang kompeten terbatas, anggaran minim, terbatasnya kemampuan sekolah melakukan komunikasi intensif memperkenalkan potensi dan prestasi sekolah ke public. Sekolah Menengah di Indonesia belum banyak melakukan terobosan komunikasi melalui Public Relations (PR) dengan baik. Institusi pendidikan menengah khususnya swasta lebih sibuk melakukan promosi mendapatkan murid, melalui propaganda iklan dan memanipulasi fakta. Sementara sekolah negeri lebih fokus pada peningkatan kemampuan akademik murid, memaksa murid mengikuti kelas tambahan untuk meraih prestise agar lulusan bisa diterima di PTN. Pendidikan menengah negeri maupun swasta belum menyadari PR mempunyai peran penting bagi pengembangan dan keberlanjutan sekolah. Grunig menggagas tentang Public Relations Model for Reputation Building, bahwa keberhasilan institusi dalam membangun reputasi ditentukan pada kemampuan melaksanakan kegiatan komunikasi bersifat two way simetrical model dengan menekankan pada komunikasi interaktif tinggi organisasi dengan publiknya, serta pesan disampaikan didasarkan pada fakta empiris. Paper ini merupakan hasil riset tentang aktifitas PR di 35 Sekolah di Semarang dengan mengelaborasi dan menyimpulkan model PR yang dominan digunakan membangun reputasi sekolah mencapai tujuan lebih efektif.
\end{abstract}

Keyword : Model Public Relations, Pendidikan Menengah, Reputasi

\section{PENDAHULUAN}

Public Relations atau yang dikenal dengan Hubungan Masyarakat di Indonesia mempunyai peran yang sangat penting bagi pengembangan kelembagaan termasuk institusi pendidikan yaitu sekolah dasar hingga perguruan tinggi. Menurut Rex Harlow, Praktisi dan Akademisi Senior menegaskan public relations adalah fungsi khusus manajemen yang berfokus pada upaya untuk mengembangkan hubungan melalui kegiatan komunikasi untuk membangungpengertian, penerimaan dankerjasama yang baik antara organisasi dengan publiknya, termasuk di dalamnya adalah pengelolaan isu dan informasi, membantu organisasi merespon dan mengelola opini publik, menjawab keinginan publik, membantu mengantisipasi trend perubuhan sikap melalui pemanfaatan teknologi dan komunikasi yang baik. Dennis L. Wilcox, $7^{\text {th }}$ (2003) Public Relations Strategies and Tactic, Pearson Education, USA, lebih lanjut dalam buku tersebut dipaparkan konsepsi lain oleh Public Relations Institute of Southern America bahwa Public Relations adalah fungsi manajemen yang menekankan pada kegiatan komunikasi untuk membangun persepsi dan strategi pengembangan hubungan yang baik antara organisasi dengan stakeholder internal dan eksternal.

Isu yang berkaitan dengan pendidikan menengah khususnya sekolah menengah atas sangat beragam dan isu tersebut berpotensi memberikan pengaruh pada berkembanganya opini negatif yang tidak menguntungkan bagi pengembangan institusi pendidikan itu sendiri. Menyimak beberapa isu negatif tersebut antara lain korupsi dana bantuan operasional sekolah (BOS), pungutan liar (Pungli), 
seleksi penerimaan siswa baru, hingga isu kekerasan yang sering dilakukan oleh guru pada murid saat proses belajar mengajar di kelas.

Menurut Rousseu opini publik itu identik dengan kebebasan, keterbukaan dalam menyampaikan ide-ide, pendapat, keinginan, kebutuhan, keluhan, kritik membangun dan keluhan dalam bentuk tulisan. Era reformasi dan keterbukaan informasi publik memberikan ruang yang lebih besar terhadap potensi opini publik. Maria, Assumpta Ruumanti, (2002) menegaskan bahwa opini publik sberkaitan dengan tugas public relations dalam bentuk kegiatan komunikasi yang diarahkan untuk lebih banyak menciptakan peluang munculnya opini publik yang positif lebih banyak daripada yang negative.

Pengelolaan pendidikan menengah agar mempunyai reputasi yang baik sangat memerlukan kontribusi public relations. Keberadaannya tidak hanya menstimulasi munculnya opini publik yang positif tetapi juga mengantisipasi munculnya trend sikap negatif stakeholder terhadap pendidikan menengah. Menurut Catatan Kantor Mentri Negara Pemberdayaan Perempuan dan Perlindungan Anak Menurut data Departemen Sosial RI tahun 2006 jumlah anak yang mengalami tindak kekerasan secara nasional mencapai 182.400 kasus. Atau data pada tahun 2006, di Jawa Tengah, sebanyak 80 persen guru mengaku pernah menghukum anak-anak dengan berteriak pada mereka di depan kelas. Sebanyak 55 persen guru mengaku pernah menyuruh murid mereka berdiri di depan kelas. Di Sulawesi Selatan, sebanyak 90 persen guru mengaku pernah menyuruh murid berdiri di depan kelas, diikuti oleh 73 persen pernah berteriak kepada murid, dan 54 persen pernah menyuruh murid untuk membersihkan atau mengelap toilet. Di Sumatera Utara, lebih dari 90 persen guru mengaku pernah menyuruh murid mereka berdiri di depan kelas, dan 80 persen pernah berteriak pada murid.

Catatan buruk pendidikan Indonesia tersebut bila tidak dikelola dengan baik akan berdampak pada rendahnya kepercayaan publik. Peristiwa selain kekerasan terhadap murid, sistem seleksi penerimaan murid baru yang dipandang tidak fair dan sarat korupsi kolusi dan nepotisme menjadi catatan reputasi tersendiri. Charles Fomburn dalam John Doorley and Haleo Fred (2007) mendeskripsikan bahwa reputasi adalah adalah keseluruhan image persepsi dari segenap stakeholder tentang organisasi. Sedangkan John Doorley menambahkan bahwa image terdiri dari komponen performa dan behaviour, aktifitas komunikasi yang dilakukan.

Menyikapi hal tersebut, muncul pertanyaan apa yang sudah dilakukan oleh pemerintah yang menangani kegiatan pendidikan menengah dan apa yang sudah dilakukan oleh pimpinan sekolah menengah sebagai penyelenggara pendidikan? Sekolah Menengah Atas yang berstatus negeri memang menjadi favorit dan pilihan utama masyarakat untuk menyekolahkan anak mereka ke jenjang lebih tinggi. Kondisi tersebut menyebabkan banyak pengelola sekolah yang tidak memandang penting pengelolaan reputasi. Asumsi yang kemudian muncul adalah tidak menggunakan kegiatan public relations pun sekolah tetap dibanjiri oleh pendaftar, sekolah bercitra tidak positif asalkan negeri juga menjadi jujukan dan rebutan orang tua murid.

Sikap penyelenggara sekolah seperti ini hampir ditemui di banyak sekolah milik pemerintah. Hal tersebut berkonsekuensi pada tidak dipandang pentingnya public relations sebagai bagian dari koalisi dominan manajemen pendidikan sekoah, untuk mengembangkan reputasi sekolah yang baik.

Hasil penelusuran di Media Online ditemukan http://sma2smg.com/ beberapa samplejob description Wakil Kepala Sekolah Bidang Kehumasan, antara lain :

1. SMA 2 Semarang

Nama Jabatan: Wakil Kepala Sekolah Bidang Komunikasi dan Kerjasama

Jobdesk :

a. Mengatur dan menyelenggarakan hubungan sekolah dengan orang tua/wali peserta didik

b. Membina hubungan antar sekolah dan komite

c. Membina hubungan antar sekolah dengan pihak luar (baik sekolah lain, instansi, perusahaan dan pihak terkait

d. Menyelenggarakan dan mengkoordinasikan rapat dinas, rapat komite, dan pertemuan rutin dalam lingkup sekolah

e. Mengkoordinasikan dan mengkomunikasikan kebijakan kepada semua warga sekolah

f. Melaksanakan dan mengkoordinasikan kegiatan-kegiatan hari besar

g. Mengkoordinasikan kegiatan pelepasan siswa

h. Menyusun Laporan kegiatan humas secara berkala 
2. SMP Islam Hidayattullah Semarang

a. Presentasi materi kegiatan

b. Menjalin keharmonisan antara warga (internal public) melalui home visit, gerakan jumat beramal, kunjungan sosial dan baksos, kunjungan ke rumah guru, Subuh Call

c. Menjalin keharmonisan dengan masyarakat umum melalui Pertemuan Guru Orang Tua Wali (PGOTW), brosur, pekan olah raga dan seni, seminar lokakarya,training, layanan internet, komite sekolah. (Jazuli, 2009)

Laporan fungsi dan kegiatan humas tersebut di atas menunjukkan bahwa humas sudah dioptimalkan di tingkat sekolah menengah. Persoalannya bila dicermati humas pada sekolah belum memaksimalkan fungsi stratejik yang baik dalam mendukung pembangunan reputasi sekolah yang baik karena masih berfokus lebih banyak pada teknikal skill daripada managerial skill. Grunig, James E dan Todd Hunt dalam Prayudi (2012) Keahlian Teknis menekankan Praktisi Public Relations memiliki keahlian di bidang komunikasi dan jurnalistik. Keahlian menagerial mendeskripsikan bahwa public relations secara sistematis merencanakan dan mengatur program public relations sebuah organisasi, memberi masukan pada manajemen dan membuat kebijaksanaan komunikasi

Berangkat dari fenomena tersebut di atas bayak sekali tugas dan fungsi humas yang belum dilaksanakan dengan baik di sekolah menengah atas. Humas praktis lebih banyak melakukan kegiatan di tataran fungsi yang paling dasar seperti membuat pengumuman dan menyampaikan informasi, tetapi luput menggarap level dan fungsi yang lebih strategis. Laura Carlsmith (2001), The Power Public Relations in School, Northwest Regional Educational Laboratory, USA menyampaikan bahwa tujuan public relations di sekolah difokuskan pada upaya membangun nilai atau kesan yang baik di kalangan orang tua murid, partner dan publik lainnya dengan fungsi spesifik yaitu menerima masukan masyarakat, mengantisipasi masalah image, mengelola kegiatan publikasi di tingkat lokal melalui newspaper, website dan lokal newsletter, melakukan kegiatan media relations seperti penulisan news release dan peliputan media lokal, melakukan kegiatan perencanaan humas yang meliputi menentukan tujuan, penyusunan materi informasi, menyusun bujet, menentukan isu kampanye, menyusun tools communication untuk semua kelompok stakeholder dan crisis communication plan, riset, poling, program penghargaan untuk murid, trainging staf humas

\section{METODOLOGI}

Penelitian ini bertujuan Mengetahui Efektifitas Pemanfaatan Model Public Relations Dalam Membangun Reputasi Sekolah Menengah Berpotensi dan Berprestasi di Kota Semarang dilakukan dengan menggunakan metode deskriptif survey, dengan populasi adalah SMU/SMK/MA di Kota Semarang sebanyak 206 sekolah dengan jumlah sampel 35 sekolah dan penentuan sampel menggunakan Proportionate Stratified Random Sampling. Pemilihan metode ini didasarkan pada pertimbangan bahwa masing-masing sekolah menengah mempunyai karakteristik yang heterogen antara sekolah negeri dan sekolah swasta

\section{HASIL PENELITIAN/ANALISIS}

Penelitian tentang Model Public Relations Untuk Pembangunan Reputasi Pendidikan Menengah Sebagai Rujukan Sekolah Berpotensi Berprestasi ini dilakukan di sejumlah sekolah yang menjadi sampel penelitian. Beberapa temuan penelitian menunjukkan hasil yang konsisten dimana mayoritas sekolah sudah mengetahui tentang Public Relations namun tidak mampu melaksanakan fungsinya dengan baik.

Perlakuan terhadap Public Relations di Sekolah hampir sama dengan di organisasi lain yang ada di Indonesia, diman public relations belum ditempatkan sebagai mitra strategis manajemen yang mempunyai andil besar dalam pencapaian tujuan organisasi. Hal tersebut dapat terlihat dari temuan penelitian berikut ini.

Latar belakang keilmuan menunjukkan seberapa besar seseorang mempunyai pengetahuan dan skill yang mendukung dalam melaksanakan tugas dan pekerjaanya. Fakta menunjukkan bahwa dari 35 sampel yang diambil, responden mayoritas berasal dari kategori sekolah SMU yaitu sebanyak 51,4\% kemudian kategori sekolah SMK sebanyak 31,4\% dan responden paling sedikit berasal dari MA yaitu sebanyak 17,1\%. Pilihan jenis sekolah lebih banyak pada SMU dikarenakan secara proporsi jumlah SMU di Kota Semarang baik negeri atau swasta jauh lebih banyak dibandingkan dengan jumlah SMK atau MA. Pelaksana pekerjaan Public Relations 
mayoritas dipegang oleh orang yang tidak memiliki latar belakang komunikasi yaitu Sarjana Pendidikan $(37,1)$, sementara yang diisi oleh tenaga berlatar belakang komunikasi hanya sebesar (5,7\%).

Praktek Public Relations di Sekolah semakin diperparah dengan status pelaksana tugas Public Relations, dimana sebanyak (71\%) dipegang oleh guru biasa, dan 29\% dikerjakan oleh Guru dengan tugas tambahan, persoalan yang kemudian muncul adalah berkaiatan dengan komitmen yang rendah dari guru biasa, karena tidak mendapatkan pengakuan formal dan kompensasi yang sebanding, guru pelaksana kegiatan humas cenderung tidak memiliki motivasi kerja yang tinggi. Akibatnya pekerjaan yang dilakukan pun hanya meneruskan tradisi yang dilakukan sebelumnya daripada mencari ide kreatif untuk melakukan perubahan.

Pelaksanaan kegiatan Public Relations yang baik ditandai dengan kemampuan Public Relations officer dalam pembuatan perencanaan atau manajemen public relations. Sebelum membuat perencanaan tentunya Public Relations harus mengetahui dengan baik target sasaran yang akan dituju, realitas yang tampak dari hasil riset ini menunjukkan pemahaman yang rendah dari para pengelola kegiatan public relations di sekolah. Hampir sebagian besar (34,3\%) hanya mampu menyebutkan empat public yang dinilai relevan yaitu murid, guru, orang tua murid dan komite sekolah, keterbatasan pengetahuan ini pada akhirnya berdampak pada ketidakmampuan melaksanaan perencanaan yang lebih strategis menjangkau semua khalayak yang relevan, bahkan ketika sekolah mengakui bahwa fokus kegiatan public relations adalah penerimaan siswa baru, public calon murid dan calon orang tua murid jarang disebut sebagai bagian dari stakeholder.

\begin{tabular}{|l|l|}
\hline 1 & $:$ Menyebutkan 1 Publik \\
\hline 2 & $:$ Menyebutkan 2 Publik \\
\hline 3 & $:$ Menyebutkan 3 Publik \\
\hline 4 & $:$ Menyebutkan 4 Publik \\
\hline
\end{tabular}

Gambar 1

Pengetahuan Public Relations Officer mengenai Tujuan PR

Berdasarkan gambar di atas dapat dilihat bahwa tujuan Public Relations yang diketahui oleh responden mayoritas hanya mampu menyebutkan satu jawaban yaitu image sebesar 74,3\%, kemudian diikuti dengan publikasi sebesar $14,3 \%$, reputasi sebesar $2,9 \%$ dan sosialisasi sebesar $8,6 \%$. Image dalam persepsi responden adalah citra yang baik yaitu banyak dikenal orang, tidak dicap sebagai sekolah anak nakal, bermutu dalam hal guru dan lulusan. Tidak banyak atau sedikit yang mampu menyebutkan perlunya melakukan komunikasi intensif dengan berbagai pihak untuk mendapatkan dukungan positif dalam bentuk sikap dan perilaku. Kemajuan positif dari Public Relations di sekolah adalah ada beberapa responden yang menyebutkan tujuan public relations adalah reputasi, meskipun ketika ditanya lebih lanjut mengenai hal tersebut responden menyatakan bahwa reputasi sama halnya dengan citra yang positif.

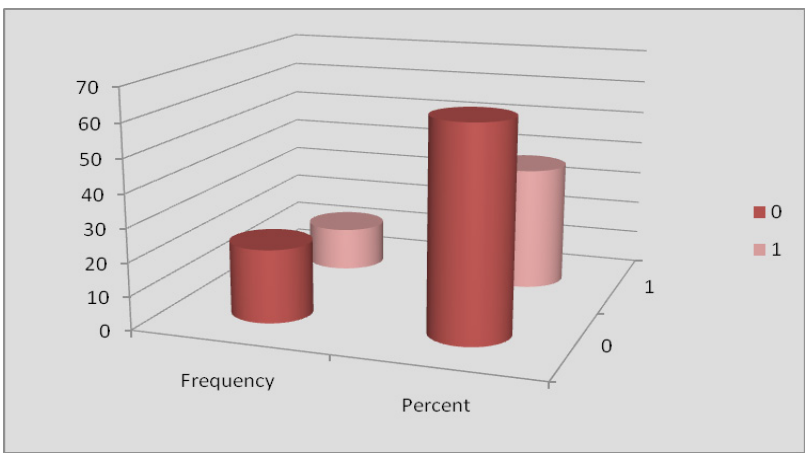

: Tidak Menggunakan Riset

: Menggunakan Riset

Gambar 2 :

PR melakukan kegiatan riset sebelum perencanaan kegiatan

Berdasarkan gambar di atas, dapat diketahi bahwa humas yang melakukan kegiatan riset sebelum pelaksaan (dinyatakan dengan angka 1) ada sebanyak 37,1\%, pada saat ditanya lebih lanjut tentang riset apa yang dilakukan sebagian hanya melihat dan membandingkan yang lebih efektif antara spanduk dan iklan di koran, belum banyak yang mampu mengetahui bahwa riset dipergunakan untuk memetakan permasalahan, menyusun skala prioritas serta menentukan target sasaran yang sesuai, sedangkan mayoritas responden yang lainnya menjawab humas yang tidak melakukan kegiatan riset sebelum pelaksanaan sebanyak $62,9 \%$. 

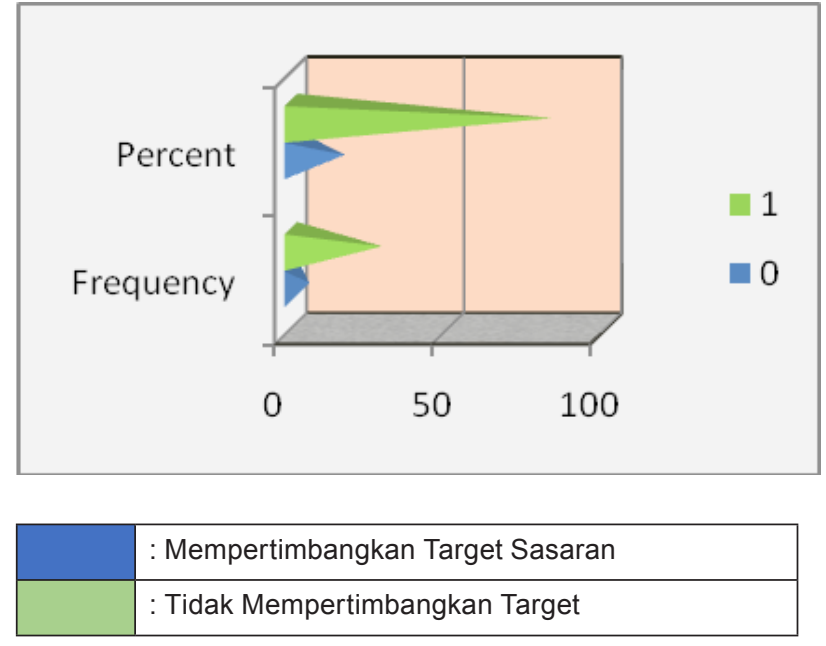

Gambar 3 :

Pemilihan Media Harus Mempertimbangkan Target Sasaran

Keterbatasan pengetahuan responden tentang stakeholder yang dituju berbanding lurus dengan temuan penelitian tentang pertimbangan pemilihan media harus memperhatikan target sasaran. Sebuah kenyataan yang ironis bahwa hampir mayoritas responden $82,9 \%$ mengakui tidak mengetahui bahwa pemilihan media yang akan digunakan harus mempertimbangkan karakteristik responden, penilaian mereka yang terpenting adalah menggunakan media yang sudah dipakai oleh pendahulunya, rata-rata mereka mengakui tidak ingin terlalu repot dan juga mempertimbangkan kendala biaya saat ingin menggunakan media yang lainnya.

Praktek public relations di sekolah SMU yang ada di Kota Semarang dapat dikatakan cukup baik hal tersebut dapat disimpulkan dari jawaban responden seputar kegiatan dasar perencanaan strategis, dasar yang dapat digunakan untuk asumsi tersebut bahwa tingkat pengatahuan tentang target sasaran yang tidak komprehensif, belum dipahaminya tentang arti penting riset dalam kegiatan perencanaan, serta tidak dipahaminya dengan baik bahwa harus ada konsistensi antara pilihan media dengan target sasaran yang dituju, kesalahan pemilihan media akan mempengaruhi efektifitas pelaksanaan kegiatan public relations sebagai sarana untuk membangun reputasi melalui penciptaan reaksi emosional yang positif.

Temuan penelitian yang dilakukan dengan wawancara dan menggunakan alat bantu kuesioner ini menunjukkan beberapa fakta penting yang bisa digarisbawahi tentang praktek pelaksanaan kegiatan
PRdiSMU KotaSemarang, melaluipenelitian tersebut terungkap bahwa PR lebih banyak menggunakan media konvensional yang berkarakteristik one way communication, dibandingkan dengan media two communication, alasan yang melatarbelakangi sangat beragam mulai dari biaya yang relatif murah hingga kemudahan dalam proses produksi.

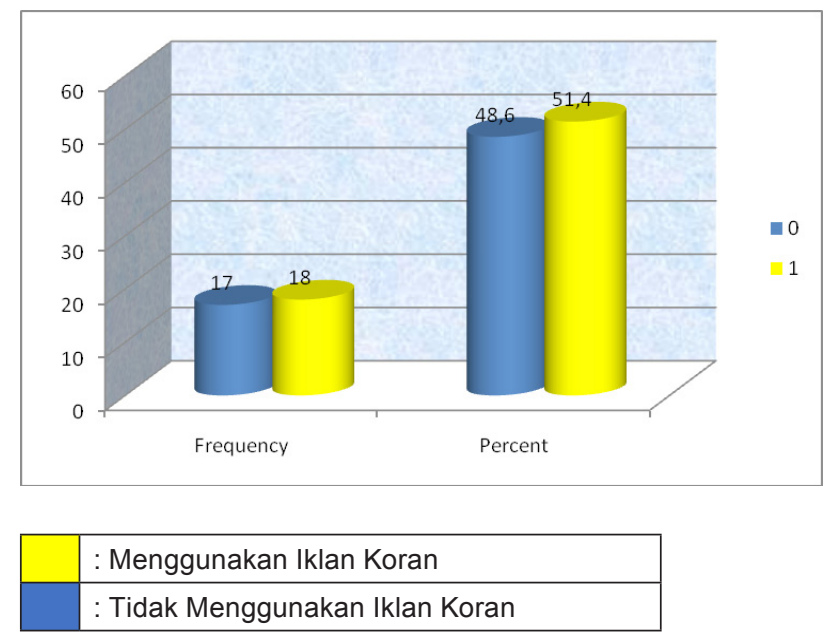

Gambar 4: Penggunaan Iklan Koran Sebagai Media PR

Fakta menarik terlihat bahwa sebagian besar sekolah menggunakan iklan di media massa cetak (koran) yaitu 51,4\%, koran lokal menjadi pilihan utama mengingat jumlah pembaca yang besar serta tingkat kesesuaian dengan target utama yang dituju. Ketika ditelusuri lebih lanjut sebagian besar menyatakan bahwa koran memang media wajib terutama ketika penerimaan siswa baru untuk menjaring murid. Hal tersebut terutama banyak dilakukan oleh sekolah swasta untuk meraih jumlah pendaftar yang besar, sementara di sekolah negeri mengaku tidak melakukan itu dengan alasan tidak beriklan peminat sudah tinggi.

Realitas ini menunjukkan gejala bahwa Public Relations dimaknai sebagai kegiatan marketing yang menjual produk/menawarkan jasa. Iklan tidak dikemas secara efektif untuk meningkatkan koginisi dan membangun afeksi positif public pada sekolah melalui tulisan iklan advetorial tentang prestasi sekolah, iklim belajar dan kompetensi guru.

Fenomena tersebut juga didukung kuat dengan pemanfaatan baliho sebagai media komunikasi. Hampir semua sekolah mengaku menggunakan baliho untuk menyampaikan pesan-pesan penting tentang sekolah terutama yang berkaitan dengan penerimaan siswa baru, sekolah swasta jor-joran 
memasang iklan tersebut dengan berebut tempat yang strategis. Satu contoh kasus untuk dua sekolah swasta yang berada di satu kawasan yang sama berebut mencari spot utama dan pertama dilihat oleh pendaftar, dengan memasang tenda, baliho, spanduk dan membagikan leaflet

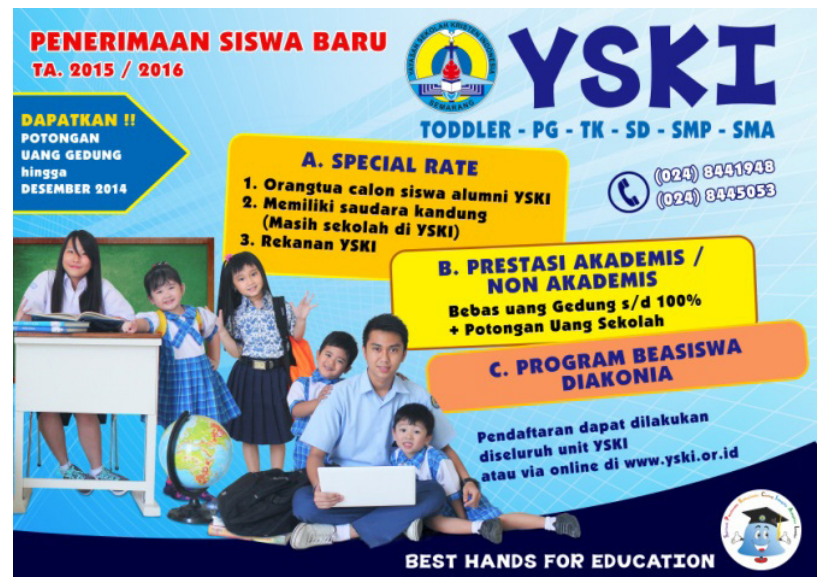

Gambar 5 : Baliho Penerimaan Siswa Baru SMA Swasta

Baliho tersebut adalah fakta empirik tentang lemahnya pemahaman pengelola public relations, baliho dipergunakan sebagai media promosi penjualan dengan menawarkan berbagai fasilitas potongan harga dan fasilitas berbagai jalur masuk, lebih memprihatinkan lagi satu media dipergunakan untuk menyampaikan beberapa level sekolah dari yayasan yang sama. Temuan penelitian yang berikutnya adalah pemanfaatan media radio sebagai public relations tools, di kalangan pengelola Public Relations di sekolah ternyta radio dinilai sebagai media yang tidak populer digunakan untuk edukasi publik.

Hampir mayoritas $(88,6 \%)$ mengaku tidak menggunakan media ini sebagai sarana komunikasi. Alasan yang muncul sangat beragam antara lain biaya terlalu mahal dan juga sekarang media radio kurang penggemar. Radio menurut mereka hanya disukaioleh kelompok pendengar dewasa dan tua, kelompok orang bermobil yang berangkat kerja sambil mendegarkan musik, sementara anak muda lebih suka dengan media online. Ketika ditanya dasarnya, hampir semua responden tidak mempunyai argumen yang kuat, termasuk ketika diinformasikan bahwa radio masih mempunyai popularitas yang baik, sangat spesifik (segmented) bahkan radio di Semarang dengan jumlah pendengar terbanyak adalah radio anak muda.

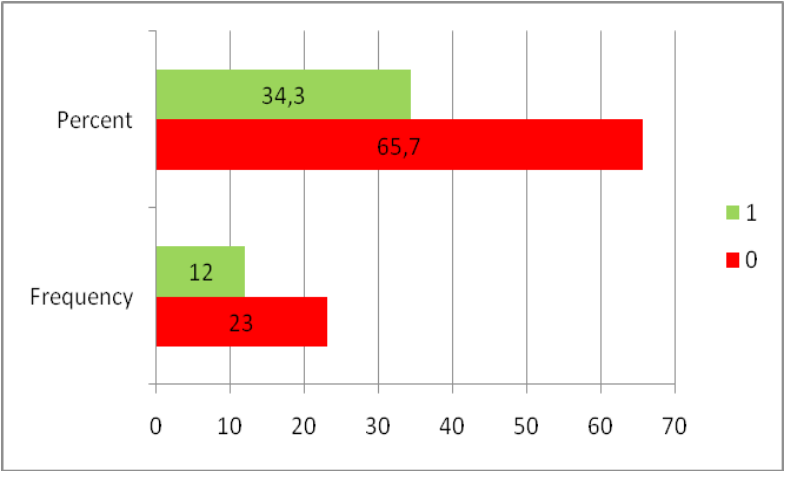

\begin{tabular}{|l|l|}
\hline : Mengirimkan Release Pra Kegiatan \\
\hline : Tidak Mengirimkan Release Pra Kegiatan \\
\hline
\end{tabular}

Gambar 7 : Buzzing PR melalui Pre Press Release

Berdasarkan data di atas diketahui bahwa mayoritas SMA/SMK/MA di Semarang tidak melakukan kegiatan media relations yaitu pengiriman release pra kegiatan ke media yaitu sebanyak 65,7\%. Ketika ditanya alasan yang mengemuka adalah sekolah tidak mempunyai bujet untuk mengirim release. Persepsi mereka segala yang berkaitan dengan wartawan dan media massa harus mengeluarkan uang. Banyak cerita dari pengelola humas di tempat yang lain bahwa bila tidak membayar wartawan berita tidak akan dimuat. Bujet yang dikeluarkan sekitar Rp. 100.000 - Rp. 200.000,- sekali kegiatan dan bagi mereka hal tersebut cukup mahal. Pada saat ditanya banyak sekali rubrik di media yang disediakan gratis tanpa bayar sebagian besar tidak mengetahui jalur untuk mengirimkannya. Tidak dikirimkannya Pemberitahuan pra kegiatan yang dilakukan sebanding lurus dengan pengiriman release setelah kegiatan. Berdasarkan gambar di atas dapat diketahui bahwa sebanyak 51,4\% responden tidak melakukan pengiriman release pasca kegiatan ke media massa, alasannya sama tidak memiliki dana dan relasi yang baik dengan media dalam hal ini wartawan. Beberapa pengelola humas mengaku bosan dan putus asa karena beberapa kali mengirimkan release kegiatan tidak ada satupun yang muncul. 


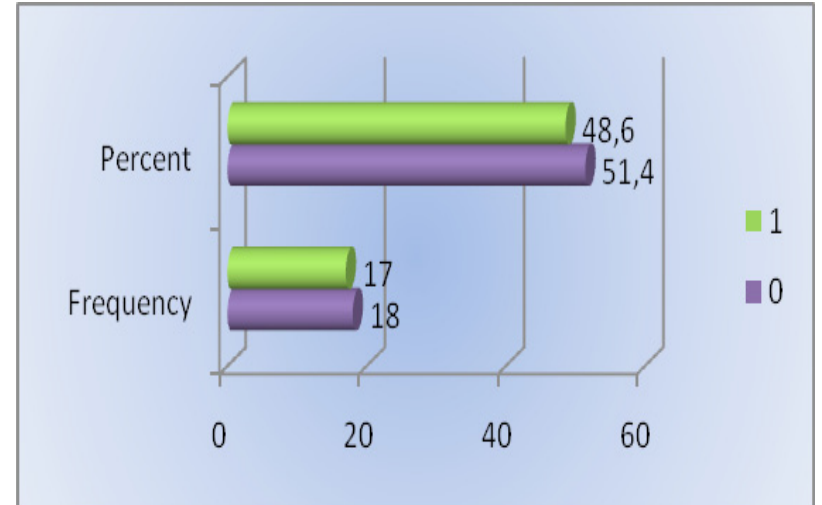

: Tidak Pengiriman Release Pasca Kegiatan

: Mengirimkan Release Pasca

Gambar 8 : Pengiriman Release Pasca Kegiatan

Berdasarkan gambar berikut dapat diketahui bahwa mayoritas responden menggunakan spanduk sebagai controle media yaitu sebanyak $91,4 \%$, lasan penggunaan spanduk biasanya untuk menjangkau targaet atau khalayak yang lebih murah dan biaya yang tidak terlalu mahal, biasanya frekuensi penggunaan spanduk meningkat saat musim Penerimaan Siswa Baru, terutama buat sekolah yang berada dalam kategori menengah ke bawah untuk menjaring murid baru. Spanduk belum dimanfaatkan secara strategis untuk menyampaikan informasi-informasi penting ke publik, malah $8.6 \%$ responden tidak menggunakan Spanduk sama sekali karena dinilai memakan tempat dan kurang efisien.
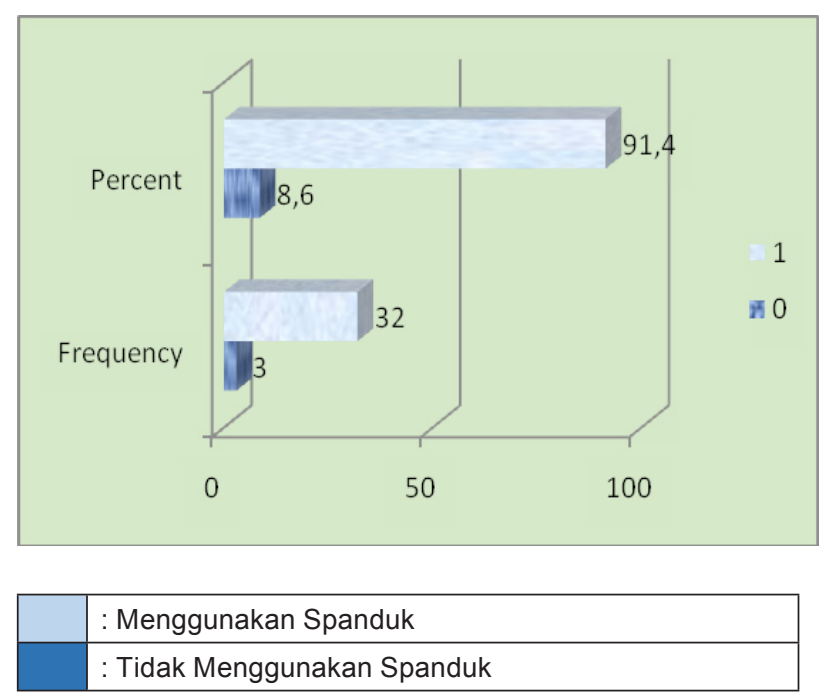

Gambar 9 : Pemanfaatan Spanduk
Pertemuan dengan orang tua sebagai salah satu event PR yang digunakan dalam kegiatan Public Relations disajikan dalam gambar berikut ini

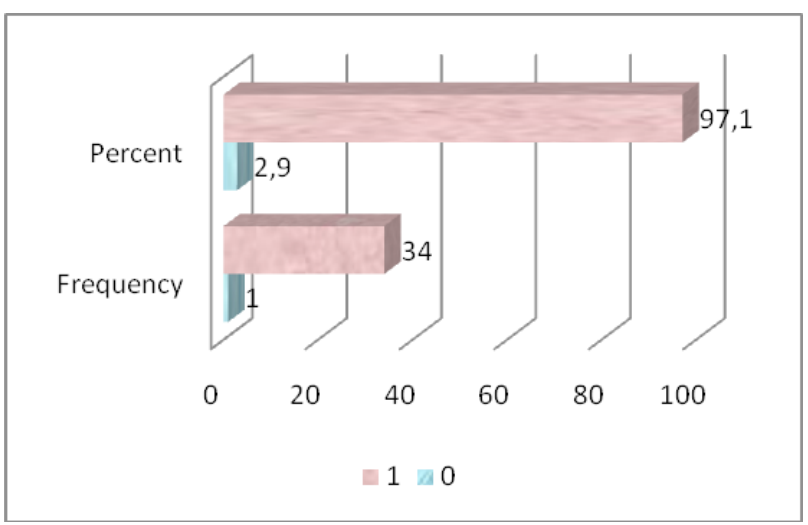

\begin{tabular}{|l|l|}
\hline : Menggunakan Pertemuan Orang tua \\
\hline : Tidak Menggunakan Pertemuan Orang tua \\
\hline
\end{tabular}

Gambar 10 : Pertemuan Sekolah dengan Orang tua

Berdasarkan gambar di atas dapat diketahui bahwa mayoritas responden menggunakan pertemuan dengan orang tua sebagai event PR yaitu sebanyak 97,1\%. Hal ini menunjukkan bahwa mayoritas sekolah SMA/SMK/MA di Semarang sudah menganggap penting event $P R$ yaitu pertemuan dengan orang tua siswa. Responden menilai bahwa kegiatan ini adalah yang paling efektif untuk menjalin hubungan dengan stakeholder terutama dengan orang tua. Pertemuan dengan orang tua bisa menjadi media komunikasi untuk menyampiakan keluhan yang dialami oleh orang tua pada sekolah, serta program-program sekolah untuk murid dan masyarakat.

Kebanyakan pertemuan dilakukan dalam satu tahun dua kali saat serah terima raport anak, tetapi sayangnya ada beberapa kelemahan mengingat tidak semua guru wali kelas bersedia menyampaikan keluhan yang dirasakan orang tua pada sekolah, begitupun ada guru yang tidak punya motivasi secara aktif untuk menyampaikan program sekolah ke murid, sehingga komunikasi dua arah tidak terjalin dan sekolah tidak mendapatkan informasi apapun dari orang tua.

Hasil pemantauan internal kebanyakan sekolah, penerimaan raport pun kadang sering diwakili oleh anak atau saudara, sehingga tidak banyak informasi yang bisa diberikan dari kedua belah pihak, bahkan di beberapa sekolah menengah raport seringtidak diambil hingga tahun ajaran baru karena alasan 
ketidakmampuan membayar biaya adminitrasi seperti SPP dan sumbangan pembangunan.

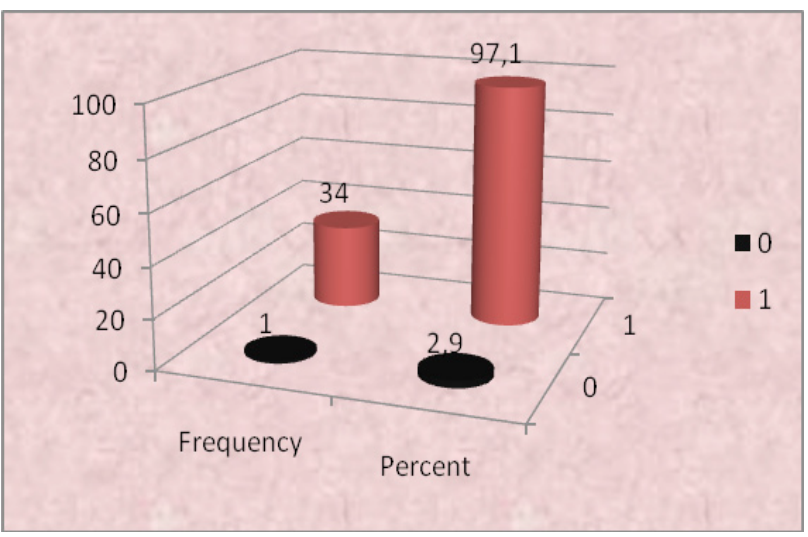

\begin{tabular}{|l|l|}
\hline : Menggunakan Briefing \\
\hline : Tidak Menggunakan Briefing \\
\hline
\end{tabular}

Gambar 11 : Briefing dengan Komite Sekolah

Berdasrkan gambar di atas dapat diketahui bahwa mayoritas responden melakukan briefing dengan komite sekolah dan menjadikannya sebagai event PR yaitu sebanyak 97,1\%. Pertemuan dengan komite sekolah diharapkan menjadi komunikasi dua rah yang baik, diman akomite memberikan kritik dan saran bagi pengembangan pembelajaran, seperti peningkatan kualitas dan komptensi guru, bahan ajar dan model pembelajaran. Komunikasi yang baik dengan komite sekolah diharapkan dapat menjadi mitra pengembangan sarana dan prasaran belajar seperti penyediaan kekurangan fasilitas sekolah melalui sponshorship.

Komite Sekolah dalam hal ini juga menjadi mediator berperan membantu mensosialisasikan peran komite bagi pengembangan sekolah sehingga memiliki pengaruh positif pada penilaian reputasi sekolah, dapat dikatakan bahwa sekolah SMA/SMK/ MA di Semarang sudah memaksimalkan kegiatan Public Relations dan sudah sadar pentingnya peran PR dalam suatu institusi.

Rapat dengan Disdik sebagai event PR yang digunakan dalam kegiatan Public Relations, kegiatan ini merupakan bentuk government relations antara sekolah dengan pemerintah Disdik. Hampir mayoritas responden menyatakan bahwa rapat koordinasi dengan Disdik sangat penting mengingat dari sini bisa diketahui program dan kebijakan terbaru di bidang pendidikan yang kemudian akan di sosialisaikan kepada murid dan masyarakat.

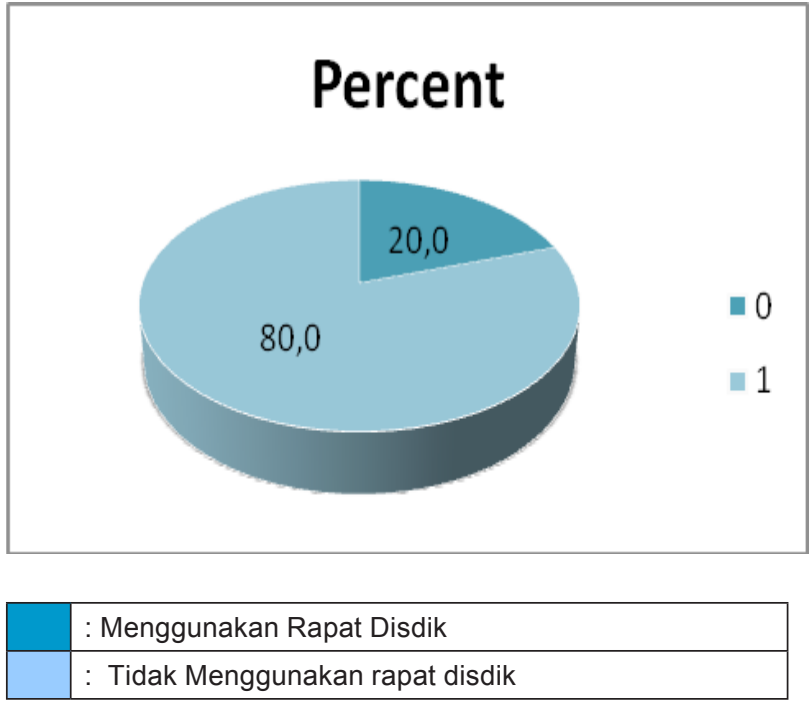

Gambar 12 : Intensitas Rapat dengan Disdik

Berdasarkan gambar di atas dapat diketahui bahwa mayoritas responden menggunakan rapat dengan Disdik sebagai event PR yaitu sebanyak 80\%. Hal ini dapat dikatakan bahwa mayoritas sekolah SMA/SMK/MA di Semarang sudah menyadari pentingnya menjalin hubungan dengan Disdik. Rapat antara sekolah dengan Disdik yang terkahir kalinya diselenggarakan membahas tentang pentingnya Akreditasi Sekolah. Hal tersebut sangat penting sekali diketahui oleh Humas, sehingga melalui Humas pihak sekolah dapat merumuskan strategi dan kebijakan untuk dapat meraih nilai akreditasi yang baik, yang merupakan bentuk pengakuan atas pengelolaan institusi pendidikan.

Sementara responden yang tidak menjawab, ketika di konfirmasi ulang bahwa responden baru saja mendapatkan tugas tambahan sebagai humas sekolah sehingga tidak mengetahui kegiatan sebelumnya.

Sosial media adalah sebuah media untuk bersosialisasi satu sama lain dan dilakukan secara online yang memungkinkan manusia untuk saling berinteraksi tanpa dibatasi ruang dan waktu. Sosial media dapat dikelompokkan menkadi beberapa bagian besar seperti social networks, discuss, share, publish, social game, MMO, virtual world, livecast, livestream, dan microblog.

Social media sebagai media cyber yang digunakan dalam kegiatan Public Relations akan sangat membantu sekali mengembangkan kualitas komunikasi antara sekolah dengan stakeholdernya. Sosmed memiliki kelebihan karena menyajikan unsur komunkasi timbal balik yang cepat, dan 
sangat menarik sekali untuk kelompok segmen tertentu terutama remaja dan anak muda.
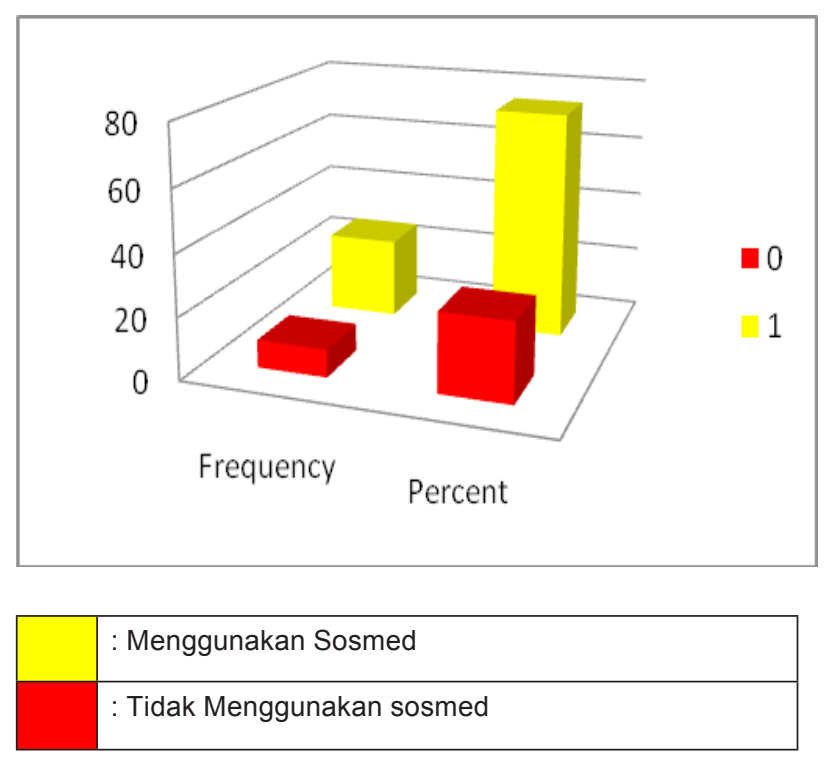

Gambar 13 : Pemanfaatan Sosmed sebagai Media PR

Berdasarakan data di atas dapat diketahui bahwa mayoritas respondeng menggunakan sosial media sebagia media cyber yang digunakan dalam kegiatan Public Relations yaitu sebanyak 74,3\%.

Selain Facebook humas juga menggunakan sosial media seperti Twiter dan beberapa menggunakan Instagram. Sosial media digunakan untuk memberikan layanan informasi yang cepat terutama pada siswa mengingat hampir sebagian besar murid menggunakan sosmed, tetapi pihak sekolah belum secara maksimal memanfaatkan sebagai media komunikasi interaktif, dimana kadangkadang jawaban atas pertanyaan yang muncul tidak langsung terjawab, mengingat tidak adanya staf kusus yang bertugas.

Hal ini meunjukkan disatu sisi bahwa sekolah SMA/SMK/MA di Semarang sudah mulai sadar dan mengetahui manfaat dan pentingnya sosial media sebagai sarana komunikasi dan informasi bagi para publiknya baikinternal maupun eksternal, sementara disisi yang lain manajemen tidak memperhatikan keberlanjutan dengan menunjuk staf yang diberikan kewenangan dan tugas penuh untuk update isi web tersebut.

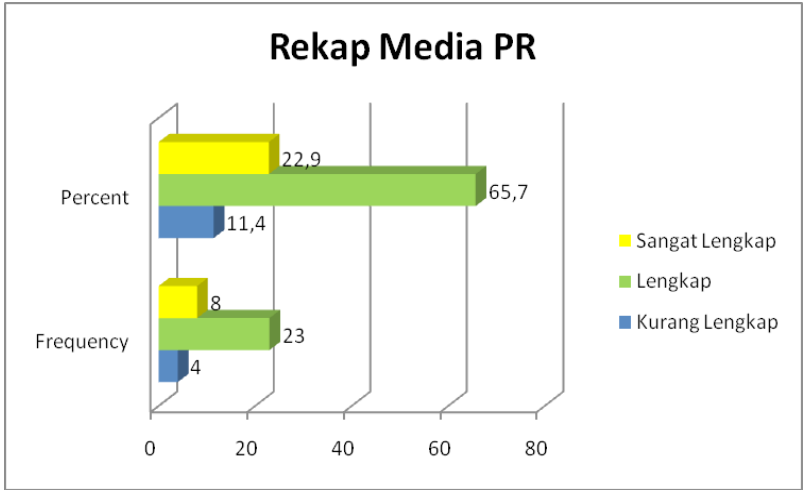

Gambar 14 : Kategorisasi Kelengkapan Pemanfaatan Media PR

Tabel di atas adalah gambaran yang menunjukkan bahwa Public Relations di Sekolah telah memanfaatkan kegiatan PR dengan baik, sebanyak $65,7 \%$ atau hampir separuh lebih menggunakan berbagai macam media yang ada seperti mading, leaflet, poster, majalah sekolah, iklan di televisi, pertemuan dengan donatur, blog dan website. Meskipun menggunakanya secara lengkap disisi lain fakta ditemukan bahwa mayoritas menggunakan media tersebut untuk kepentingan promosi atau jualan khususnya sekolah swasta dengan mayoritas kontent adalah penerimaan siswa baru

Sedangkan sekolah negeri lebih memanfaatkan peluang untuk dapat beriklan di koran secara gratis melalui rilis yang di kirim ke media massa, meskipun tingkat kemunculannya kecil hal tersebut berpengaruh positif terhadap citra lembaga. Temuan penelitian juga mengungkapkan belum dimanfaatkannya media relations tools sebagai media yang efektif dan efisien, mengingat hampir mayoritas tidak mengetahui cara efektif mengembangkan hubungan yang baik dengan wartawan.

Keberhasilan PR dalam mengelola reputasi lembaga sangat dipengaruhi sekali pada persepsi institusi dan pengelola public relations tentang pentingnya public relations. Persepsi yang tidak baik akan menempatkan public relations pada posisi terbelakang dan tidak strategis, hasil penelitianberikutnya mencoba untuk mengungkapkan persepsi pengelola PR terhadap arti penting PR bagi pengembangan sekolah. 


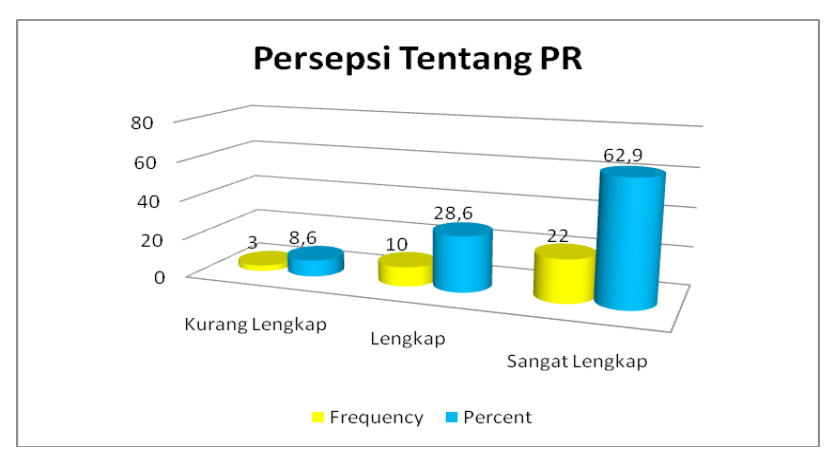

\begin{tabular}{|l|l|}
\hline & $:$ Kurang Penting \\
\hline & $:$ Penting \\
\hline & $:$ Sangat Penting \\
\hline
\end{tabular}

Gambar 15 : Persepsi PRO Terhadap Pentingnya Public Relations Bagi Sekolah

Data di atas menunjukkan temuan penelitian yang menggembirakan bahwa hampir semua responden menyatakan public relations sangat penting bagi pengembangan sekolah. Sebanyak $62,9 \%$ menunjukkan sikapsangat positif tentang posisi public relations, sedangkan $28,2 \%$ juga memiliki kecenderungan sikap yang sama. Dalam persepsi responden Kegiatan Humas berperan besar dalam pembentukan reputasi sekolah, melalui kegiatan komunikasi yang dilakukan humas idealnya mampu menjembatani kepentingan berbagai pihak yang terlibat dalam kegiatan sekolah, selain itu public relations juga dipersepsi sebagai penentu utama keberhasilan sekolah dalam mengembangkan reputasi sebagai sekolah rujukan berprestasi dan berpotensi, humas berkewajiban untuk mengelola dan menjaga bila ada rumor, isu maupun krisis yang mengganggu nama baik institusi sekolah.

Di sisi yang lain humas juga menyatakan sikapnya yang positif agar divisi public relations didukung dengan tenaga yang memadai secara kuantitas dan kualitas. Persetujuan dan sikap atas pernyataan tersebut didasarkan pada selama ini pekerjaan humas banyak tidak terurus. Sekolah mempunyai wakasek humas tetapi selama ini belum secara optimal mampu melaksanakan pekerjaan humas, pekerjaan teknis seperti membuat leaflet, spanduk, merchandise, baliho tidak tertangani dengan baik.

Dalam prakteknya wakasek bidang kehumasan memang dibantu oleh tenaga guru dan staf administrasi, tetapi kebanyakan guru tersebut tidak memiliki waktu yang cukup karena kesibukan mengajar dan melaksanakan tugas sebagai guru, sedangkan tenaga administrasi lebih fokus pada tugas administrasi sekolah. Hal ini dapat disimpulkan bahwa humas sekloah SMA/SMK/MA di Semarang perlu diberikan anggota yang cukup agar kegiatan promosi dan publikasi sekolah menjadi baik. Selain itu meskipun staf humas menurut persepsi tidak harus berasal dari latar belakang keilmuan public relations, semua responden tetap sepakat agar bisa meningkatkan performa kerja public relations harus memiliki skill komunikasi yang relevan.

\section{DISKUSI}

Perkembangan Public Relations di Indonesia menunjukkan tren yang positif, oleh beberapa instansi PR sudah dianggap menjadi bagian penting dalam organisasi yang dilibatkan dalam setiap pengambilan keputusan. Ditengah perkembangan PR yang sangat pesat di sektor Industri, fakta atau realitas PR belum dioptimalkan dalam pengembangan sektor pendidikan di Indonesia.

Praktek PR di Indonesia terutama di sekolah menengah atas hanya lebih menekankan pada pekerjaan promosi, jualan sekolah dan menjaring murid. Hal ini mengingkari konsepsi PR yang lebih pada kegiatan komunikasi untuk memelihara dan mengembangkan sikap. Seperti yang disampaikan oleh British Institute of Public Relations yang dikutip dalam Iriantara (2013:5) bahwa PR adalah upaya yang disengaja dan berkelanjutan untuk membangun dan memelihara saling pengertian antara organisasi dengan publiknya.

Senada dengan hal tersebut di atas Lattimore (2010 4) menyajikan gagasan yang lebih jelas tentang PR adalah fungsi kepemimpinan dan manajemen yang membantu pencapaian tujuan organisasi, membantu mendefinisikan filosofi, serta memfasilitasi perubahan organisasi. Para praktisi PR berkomunikasi dengan public internal dan eksternal yang relevan untuk mengembangkan hubungan yang positif serta menciptakan konsistensi antara tujuan organisasi dengan harapan masyarakat. Pertanyaan yang muncul atas konsep tersebut di atas adalah bagaimana pemahaman dan praktek PR di sekolah baik negeri maupun swasta.

Hasil penelitian yang dilakukan secara survey di 35 sekolah menengah atas di Kota Semarang baik SMA/SMK/MA menunjukkan hasil bahwa rata-rata mengerti kegiatan humas/PR, tetapi yang dipahami hanya sebatas kegiatan promosi sekolah terutama saat penerimaan siswa baru. Sekolah swasta di 
Semarang berlomba melakukan promosi yang besar dalam rangka menjaring siswa sebanyak banyaknya.

Realitas ini menunjukkan lemahnya kualitas penyelenggaraan PR di sekolah menengah atas di Semarang, PR belum mampu membedakan fungsi public relations dengan fungsi marketing. Humas yang mengelola sekolah lebih berperan sebagai tenaga penjualan yang mencari murid baru, membuat materi promosi luar ruang serta mendistribusikannya. Dinas Pendidikan dan Sekolah perlu memahami dan menerjemahkan kembali fungsi esensial Humas seperti diungkapkan NDEA dalam Iriantara (2013:19) Humas pendidikan adalah salah satu fungsi manajemen yang terencana dan sistematis yang membantu memperbaiki programprogram dan layanan organisasi pendidikan.

Konsep tersebut menegaskan bahwa fungsi humas tidak cuma sekadar membuat alat bantu promosi, tetapi lebih pada kegiatan planning PR yang selama ini dari hasil jajak pendapat tidak banyak humas sekolah yang melakukan dengan baik. Humas sekolah harus lebih cerdas merancang kegiatan PR yang memiliki substansi pada komunikasi dua arah yang komprehensif dengan publik yang relevan.

Hal tersebut di atas senada dengan yang disampaikan oleh Grunig dalam Kriyantono (2014:96) bahwa PR sebagai penggunaan komunikasi untuk memanipulasi publik untuk keuntungan organisasi, maka model press agentry, public information, dan two way asymetric masih bersifat asimetris yang mencoba mengubah perilaku publik tanpa dibarengi dengan mengubah perilku organisasi.

Grunig menekankan bahwa semua organisasi dalam melakukan praktek PR harus lebih menonjolkan pada terciptanya komunikasi dua arah, sementara selama ini dari hasil survey yang dilakukan frekuensi dan bujet anggaran PR lebih banyak dilakukan utuk produksi media-media yang kategorinya one way communication. Penggunaan media yang memiliki karakteristik komunikasi satu arah tidak mampu secara efektif membangun sikap yang positif, lebih menekankan pada penyebarluasan informasi organisasi ke publik dengan content yang cenderung propaganda, dengan menarik perhatian khalayak.

Fakta tentang banyaknya sekolah yang melakukan kegiatan PR bersifat satu arah terlihat dari beberapa sample spanduk dan baliho berikut ini :

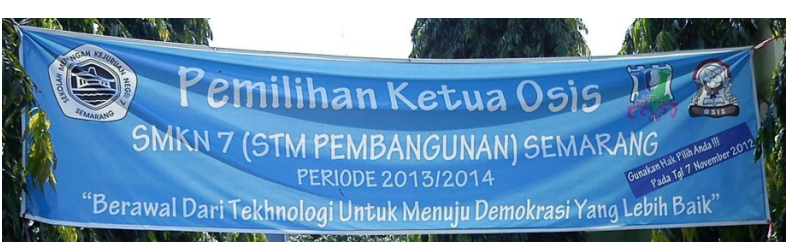

Gambar 16 : Spanduk Komunikasi Internal

Dokumentasi tersebut di atas menunjukkan humas melaksanakan kegiatan komunikasi internal cukup baik, inistifterbut sayangnya kurang dibarengi dengan kegiatan yang sifatnya komunikasi dua arah. Spanduk tersebut hanya berfungsi mengingatkan tentang kegiatan. Spanduk pada dasarnya sangat efektif dipergunakan sebagai media buzzing yang menstimulasi terciptanya komunikasi dua arah yang baik. Isi informasi pesan tersebut tidak disertai dengan kontak informasi bila ada segenap khalayak yang membutuhkan informasi lebih detail.

Selain spanduk media komunikasi satu arah yang digunakan antara lain baliho, leaflet, ada beberapa yang menggunakan poster. Berikut ini disajikan tambel yang menggambarkan media yang digunakan dalam kegiatan kehumasan di sekolah menengah atas di Kota Semarang.

Pelaksanaan kegiatan PR yang ideal dilakukan dalam kerangka dialogis untuk mencapai tujuan yang telah ditetapkan. Grunig \& Hunt dalam Kriyantono (2014:100) memandang dialog sebagai elem kunci membangun hubungan yang baik antara organisasi dengan publik. Dialog merupakan prasyarat menentukan legitimasi perilaku perusahaan di mata publiknya. Artinya publik akan merasa bahwa melalui dialog perusahaan telah berkeinginan membangun sistem komunikasi yang menjembatani perusahaan dengan publik.

Esensi praktek PR yang bersifat dialogis belum dilaksanakan secara optimal, berikut data perbandingan penggunaan media.

Dari data tersebut terlihat bahwa sebagian besar lebih banyak menggunakan media yang berkarakteristik one way communication sebanyak $69 \%$ di bandingkan dengan media two way communication (31\%). Penggunaan media yang bersifat one way hanya bertujuan untuk memberikan informasi sedikit efektif untuk bisa merubah sikap dari target sasaran. Sedikitnya pemanfaatan media two way communication sedikit membantu organisasi menyesuiakan diri dengan kepentingan stakeholder.

Dalam prakteknya memang ada beberapa media 
komunikasi yang sifatnya dua arah diterapkan dalam praktek kegiatan PR di sekolah, tetapi bila dilihat dari intensitas komunikasi yang dilakukan dapat dikategorikan sangat jarang, di hampir mayoritas sekolah kegiatan komunikasi antara orang tua dan anak hanya dilakukan satu semester sekali yaitu ketika penerimaan raport, meskipun di beberapa sekolah terutama sekolah swasta favorit mengatakan bahwa wali kelas juga sering melakukan kontak dengan orang tua murid meskipun dilakukan secara tidak langsung untuk melaporkan perkembangan siswanya.

Sekolah melalui kegiatan PR idealnya mampu menyerap keinginan stakeholder misal mengenai kualitas belajar mengajar, faktor yang berpengaruh terhadap prestasi murid, sarana belajar yang memadai serta kritik lainnya untuk kemajuan sekolah yang dilakukan oleh orang tua murid atau komite sekolah, lebih strategis PR memiliki peran menjadi perantara komunikasi antar organisasi dengan publik, mengamankan protes yang disampaikan secara tidak terstruktur dan kadang cenderung anarkis, serta meredam munculnya gosip lewat word of mouth dikalangan para ortu atau siswa terhadap sekolah. Lesly lebih lanjut menegaskan bahwa PR idealnya mampu mencipatkan saling pengertian antara organisasi dengan kelompok public yang berpengaruh lewat komunikasi yang baik, PR juga berepran memfasilitasi kebebasan dalam menyampaikan kritik dan masukan bagi stakeholder

Grunig dalam banyak literasi PR menekankan bahwa substansi penyelenggaraan PR lebih pada praktik komunikasi dua arah. Berikut model assimetric Public Relations. Idealnya sekolah dapat mengadopsi mix motives model (simetris) dalam merancang kegiatan PR, hal tersebut memberikan banyak keuntungan di bandingkan dengan penggunaan model public information. Penggunaan model ini dapat diterapkan kepada semua publik yang relevan, salah satunya adalah media massa baik cetak, TV dan online. Media massa oleh sekolah belum dipandang sebagai mitra yanng strategis, temuan penelitian menunjukkan bahwa kewajiban sekolah hanya sebatas mengirimkan release ke media massa tanpa memikirkan startegi yang tepat agar release tersebut dimuat secara intensif. Praktek Public Relatios di organisasi sekolah harus dikelola secara profesional dan strategis, PR tidak boleh disalahfungsikan sebagai marketing sekolah, sementara fungsi PR hanya sedikit diperankan. Kesalahan praktek PR disekolah ini lebih pada aspek belum dipersepsinya PR sebagai bagian strategis koalisi dominan manajemen. Di hampir semua sekolah meskipun mempunyai wakasek bidang kehumasan, Ruang PR masih menumpang pada bagian admin sekolah, tenaga atau staf yang membantu juga masih menggunakan tenaga admin sekolah.

Temuan penelitian dibawah ini yang dilakukan melalui studi dokumentasi pada laman resmi sekolah masing-masing menunjukkan bahwa PR belum dipandang startegis dari posisi serta jalur koordinasi dan komunikasi. Peraturan pemerintah yang dirujuk tidak memberikan kemudahan dan support optimalisasi fungsi PR di sekolah. Wakasek komunikasi/ humas tidak memiliki staf khusus yang menangani pekerjaan humas, hal tersebut berpengaruh pada hasil pekerjaan humas yang tidak optimal.

\section{KESIMPULAN}

Public Relations mempunyai perann yang sangat penting bagi pengembangan kelembagaan pemerintah maupun swasta salah satunya adalah institusi pendidikan. Penelitian tentang Model Public Relations Untuk Pembangunan Reputasi Sekolah Rujukan Berpotensi dan Berprestasi ini menghasilkan temuan penting sebagai berikut :

1. Praktisi Humas di SMU tidak memiliki pengetahuan yang baik tentang praktik PR mengingat hampir sebagian besar responden hanya mampu menyebutkan 4 jenis Public yaitu $34.3 \%$, keempat jenis public yang populer tersebut adalah siswa, orang tua murid, guru dan masyarakat.

2. Berkaitan dengan perencanaan PR hampir semua responden mengaku melakukan kegiatan perencanaan dengan baik, tetapi hal tersebut tidak sejalan dengan pengakuan responden yang mana hampir separuh lebih (62,9\%) mengaku tidak melakukan kegiatan riset sebelum pelaksanaan kegiatan humas. Humas yang melakukan kegiatan riset ketika ditelusuri lebih lanjut bentuknya hanya membandingkan efektifitas iklan di koran dengan media luar ruang.

3. Tujuan Public Relations oleh mayoritas responden $(74,3 \%)$ mengaku bahwa pelaksanaan kegiatan PR adalah untuk mendapatkan image (citra) yang baik. Dari sekian banyak responden tidak ada satupun yang mengetahui bahwa tujuan PR membangun reputasi dengan evaluasi 
keberhasilan yang terukur dari perspektif social maupun bisnis.

4. Model Public Relations mengacu pada konsep PR model Grunig, PR disekolah lebih banyak menggunakan strategi Public Informations Model, yang mana riset yang digunakan melandasi perencanaan PR dianggap tidak terlalu penting. Fokus utama pada setiap pelaksanaan kegiatan PR yang terpenting adalah informasi mampu disajikan secara cepat

5. Kegiatan PR yang berkarakteristik two way communication hanya dilakukan sekali pada tiap semesternya, itupun hanya kepada stakeholder tertentu seperti guru dengan murid saat penerimaan raport dan juga antara pengelola sekolah dengan komite untuk menyerap kebutuhan yang diperlukan, sementara dengan kelompok stakeholder lainya tidak atau jarang dilakukan seperti media gathering, government relations dan consummer relations.

Rekomendasi yang dapat diberikan untuk mengatasi persoalan tersebut adalah Perlunya dilakukan Penelitian Lebih lanjut tentang FaktorFaktor yang mempengaruhi Reputasi sekolah dalam Perspektif Teori Sistem dan Stakeholder Theory, sehingga PR mampu mengetahui tentang seberapa penting keberadaan organisasi dibutuhkan oleh publik dan persepsi publik terhadap performa organisasi sekolah, sehingga mampu didesai model public relations yang paling efektif.

\section{DAFTAR PUSTAKA}

Dennis L. Wilcox, $7^{\text {th }}$ (2003). Public Relations Strategies and Tactic. USA : Pearson Education

Doorley, John and Helio Fred Gracia. (2007). Reputation Managemant. New York : Routledge

Iriantara, Yosal, (2013). Manajemen Humas Sekolah, Bandung : Simbiosa Rekatama Media

Laura Carlsmith (2001), The Power Public Relations in School, USA : Northwest Regional Educational Laboratory

Dan Lattimore, Otis Baskin, Suzette T. Heiman, Elizabeth L. Toth, 2010. Public Relations Profesi dan Praktik, Mac Graww-Hill Education Salemba Humanika, Jakarta

Lesly, Philip, 1993, Everything You Wanted to Know about Public Relations. Fourth Edition. Singapore: Probus Publishing Company

Maria, Assumpta Ruumanti, (2002). Dasar Dasar Public Relations Teori dan Praktek, Jakarta : Grasindo

M. Syaifudin Jazuli, (2009). Skripsi Manajemen Humas Pada Lembaga Pendidikan Islam Studi di SMP Islam Hidayatullah Banyumanik Semarang, Semarang : Fakultas Tarbiyah IAIN Walisongo

Prayudi, (2008). Manajeman Isu Pendekatan Public Relations. Yogyakarta : Pustaka Adipura

Sumber lain

http://sma2smg.com/ diunduh tanggal 1 Mei 2014 pukul 21.00 WIB

http://smpk.yski.info/ diunduh tanggal 29 Agustus 2015 pukul 19:00 